\title{
Pecan agroforestry systems improve soil quality by stimulating enzyme activity
}

\author{
Zhaocheng Wang ${ }^{\text {Equal first author, } 1}{ }^{1}$, Mengyu Zhou ${ }^{\text {Equal first author, }{ }^{1}, \text { Hua Liu }}{ }^{1}$, Cheng Huang $^{1}$, Yuhua Ma $^{1}$, Hao xin Ge $^{2}$, Xiang \\ $\mathbf{G e}^{2}$, Songling Fu ${ }^{\text {Corresp. } 1}$ \\ ${ }^{1}$ School of Forestry and Landscape Architecture, Anhui Agricultural University, Hefei, Anhui, China \\ 2 Fuyang Xinfeng Seed Industry Co., Ltd., Fuyang, Anhui, China \\ Corresponding Author: Songling Fu \\ Email address: fusongling@ahau.edu.cn
}

Background . Forest and plantation intercropping are efficient agroforestry systems that optimize land use and promote agroforestry around the world. However, diverse agroforestry systems on the same upper-plantation differently affect the physical and chemical properties of the soil.

Methods. The treatments for this study included a single cultivation (CK) pecan control and three agroforestry systems (pecan + Paeonia suffruticosa + Hemerocallis citrina, pecan + Paeonia suffruticosa, and pecan + Paeonia lactiflora). Soil samples were categorized according to the sampling depth (0-20 $\mathrm{cm}, 20-40 \mathrm{~cm}, 40-60 \mathrm{~cm}$ ).

Results. The results demonstrated that the bulk density (BD) of soil under the pecan agroforestry system (PPH and PPL) was reduced by $16.13 \%$ and $7.10 \%$, respectively, and the soil moisture content (MC) and total soil porosity (TPO) increased. Improvements in the physical properties of the soil under the PPS agroforestry system were not obvious when compared with the pecan monoculture. The soil total phosphorus (TP), total nitrogen (TN), available potassium (AK), and total carbon (TC) increased significantly, while the soil urease (S-UE), alkaline phosphatase (S-AKP), and 1,4- $\beta$-N-acetylglucosamines (S-NAG) enzyme activity also increased significantly, following agroforestry. Overall, the pecan agroforestry system significantly improved the physical properties of the pecan plantation soil, enriched the soil nutrients, and increased the activity of soil enzymes related to TC, TN, and TP cycles. 
1 Pecan agroforestry systems improve the soil quality by stimulating the enzyme activity 2

3 Zhaocheng Wang Equal first author, 1 , Mengyu Zhou Equal first author, ${ }^{1}$, Hua Liu ${ }^{1}$, Cheng 4 Huang ${ }^{1}$, Yuhua $\mathrm{Ma}^{1}$, Haoxin $\mathrm{Ge}^{2}$, Xiang $\mathrm{Ge}^{2}$, Songling Fu Corresp. 1

$6 \quad{ }^{1}$ School of Forestry and Landscape Architecture, Anhui Agricultural University, Hefei, Anhui, 7 China;

$8 \quad$ 2Fuyang Xinfeng Seed Industry Co., Ltd. Fuyang, Anhui, China

$9 *$ These authors contributed equally to this work.

11 Corresponding Author:

12 Songling $\mathrm{Fu}^{1}$

13130 Changjiangxi Road, Hefei, Anhui, 230036, China

14 Email: fusongling@ahau.edu.cn 
16 ABSTRACT

17 Background. Forest and plantation intercropping are efficient agroforestry systems that optimize

18 land use and promote agroforestry around the world. However, diverse agroforestry systems on

19 the same upper-plantation differently affect the physical and chemical properties of the soil.

20 Methods. The treatments for this study included a single cultivation (CK) pecan control and

21 three agroforestry systems (pecan + Paeonia suffruticosa + Hemerocallis citrina, pecan +

22 Paeonia suffruticosa, and pecan + Paeonia lactiflora). Soil samples were categorized according

23 to the sampling depth $(0-20 \mathrm{~cm}, 20-40 \mathrm{~cm}, 40-60 \mathrm{~cm})$.

24 Results. The results demonstrated that the bulk density (BD) of soil under the pecan agroforestry 25 system (PPH and PPL) was reduced by $16.13 \%$ and $7.10 \%$, respectively, and the soil moisture content (MC) and total soil porosity (TPO) increased. Improvements in the physical properties of

27 the soil under the PPS agroforestry system were not obvious when compared with the pecan monoculture. The soil total phosphorus (TP), total nitrogen (TN), available potassium (AK), and total carbon (TC) increased significantly, while the soil urease (S-UE), alkaline phosphatase (SAKP), and 1,4- $\beta-\mathrm{N}$-acetylglucosamines (S-NAG) enzyme activity also increased significantly,

31 following agroforestry. Overall, the pecan agroforestry system significantly improved the

32 physical properties of the pecan plantation soil, enriched the soil nutrients, and increased the

33 activity of soil enzymes related to TC, TN, and TP cycles. 


\section{INTRODUCTION}

Soil is foundational for terrestrial ecosystems and its cumulative functions and microbial characteristics have the potential to alter environments on a global scale (Rillig et al., 2019; Wilson \& Lovell, 2016). The physicochemical properties (Chen et al., 2019) and enzyme activity (Wang et al., 2017) of soils are typically considered to be important indicators of soil quality (Paz-Ferreiro \& Fu, 2013). Soil enzymes participate in the decomposition of soil organic matter and play a key catalytic role. Organic matter is decomposed into nutrients for plants and improve the quality of the soil (Ren et al., 2016). The properties of soil, including the availability of nutrients and enzyme activity, typically vary with soil depth and can lead to inconsistent topsoil quality and subsoil factors (Yang et al., 2021).

Agroforestry is a sustainable land management system used to maintain soil fertility and productivity (Dollinger \& Jose, 2018; Isbell et al., 2017). The combination of tree and crop systems can optimize planting areas more effectively than individual tree systems (Torralba et al., 2016). It can promote the creation of jobs and generate income while protecting biodiversity and ecosystem services (Muchane et al., 2020; Santos et al., 2019). Many studies have shown that, in contrast to monocultures, agroforestry intercropping may promote a variety of agroecosystem services by increasing yields and improving soil quality and soil carbon sequestration (Kimura et al., 2018; Ma et al., 2017; Paul et al., 2018; Žalac et al., 2021; Zhang et al., 2021). Agroforestry may also increase the content of soil organic carbon and total nitrogen (Lian et al., 2019; Lu et al., 2015). Improvements have also been shown in the physical properties (Chen et al., 2019), levels of available soil nutrients ( $\mathrm{N}$ and $\mathrm{K}$ ), and enzyme content (urease and acid phosphatase) of the soil (Tang et al., 2020). 
58 Pecan (Carya illinoinensis) is a valuable nut tree popular in China (Sagaram et al., 2007). Anhui

59 Province was the first area to introduce pecans, and it has since become one of the main

60 cultivation areas in China (Zhang et al., 2015). In recent years, cultivation techniques (Luo et al.,

61 2016), nut quality (Atanasov et al., 2018), the chemical constituents of plant fruits (Fernandes et

62 al., 2017), and the components and utilization of fruit shells (Martinez-Casillas et al., 2019) have

63 been studied to optimize the economy of the pecan. Pecan trees require large cultivation areas

64 and extended growing periods (Zhang et al., 2015). Woody crops, including peony, which is

65 used for oil, herbaceous peony with medicinal value, and day lily are widely planted across

66 northern subtropical China for their ecological and economic profitability (Yang et al., 2018).

67 Pecan plantations are typically intercropped with other cash crops in agroforestry ecosystems,

68 including Salvia miltiorrhiza and Arachis hypogaea. The transition from pecan monocultures to

69 agroforestry systems is based on the ability of pecans to improve soil quality, soil fertility, and to

70 improve the sustainability of farmlands (Gao et al., 2019; Sagastuy \& Krause, 2019).

71 There have been few studies on the interactions between soil nutrients and soil enzyme

72 activity under different agroforestry patterns of Carya cathayensis in northern subtropical China.

73 We believe that the agroforestry management of pecans impacts soil quality. We studied three

74 agroforestry systems (pecan + Paeonia suffruticosa + Hemerocallis citrina $(\mathrm{PPH})$, pecan +

75 Paeonia suffruticosa (PPS), and pecan + Paeonia lactiflora (PPL)), and a pecan monoculture

76 (CK) to understand the effects of pecan compounds on soil quality (particularly its physical and

77 chemical properties and enzyme activity).

We hypothesized that: the soil structure of pecan monocultures would be poor with low

79 nutrient content; different agroforestry systems may improve the physical properties of the soil,

80 optimize its structure, and enrich its nutrients to a certain extent; and the enzyme activity in the 
81 soils of different pecan agroforestry intercropping systems would be higher than that of

82 monoculture systems.

\section{MATERIALS \& METHODS}

\section{Experimental site description and design}

85 The study was conducted at a pecan orchard in Wenji in the Yingquan District of Fuyang City,

86 Anhui Province, China $\left(33^{\circ} 3^{\prime} \mathrm{N}, 115^{\circ} 36^{\prime} \mathrm{E}\right)$. This area has a warm temperate semi-humid

87 monsoon climate with an annual average temperature of $14.9^{\circ} \mathrm{C}$ and an annual average

88 precipitation of $889 \mathrm{~mm}$. The maximum temperature for this area was $41.4^{\circ} \mathrm{C}$ and the minimum

89 temperature was $-20.4^{\circ} \mathrm{C}$ (China Meteorological Data Service, http://data.cma.cn/).

90 The afforestation of the experimental site occurred in 2016 using the 'Pawnee' variety of

91 tree in the second year of growth. Rows were spaced $4.0 \mathrm{~m} \times 6.0 \mathrm{~m}$. Three types of perennials

92 (Paeonia suffruticosa, Hemerocallis citrina, and Paeonia lactiflora) were planted in the pecan

93 plantation in 2017. A randomized block design was adopted for the study in September 2019

94 consisting of four treatments and three replicates. The treatments included: (1) PPH, with a row

95 spacing of Paeonia suffruticosa of $0.2 \mathrm{~m} \times 0.2 \mathrm{~m}$ and Hemerocallis citrina spaced at $0.4 \mathrm{~m} \times 0.8$

$96 \mathrm{~m}$; (2) PPS, with the row spacing of Paeonia suffruticosa at $0.2 \mathrm{~m} \times 0.6 \mathrm{~m}$; (3) PPL, with the row

97 spacing of Paeonia lactiflora at $0.2 \mathrm{~m} \times 0.6 \mathrm{~m}$; (4) pecan monoculture $(\mathrm{CK})$.

\section{Soil sampling}

99 Soil samples were collected from the experimental site in September 2019. Eight pecan seedlings

100 represented one plot, and three plots were randomly established for each treatment in the selected

101 sampling area. A shovel was used to remove the plants and the surface litter from the soil. Five

102 random soil profiles were obtained using a zig-zag sampling pattern (Tafesa et al., 2019) at 
103 depths of $0-20 \mathrm{~cm}, 20-40 \mathrm{~cm}$, and $40-60 \mathrm{~cm}$. The samples were then mixed to generate a soil

104 sample for each layer. A total of 36 soil samples were collected from the four treatment sites.

105 The samples were sealed in plastic bags and transported to the laboratory. Soil samples were

106 dried to determine their physicochemical properties and were kept in refrigerator at $4^{\circ}$ for

107 determining enzyme activities.

\section{Soil physicochemical properties analysis}

109 Soil samples were collected using the ring knife method to determine their moisture content

110 (MC), bulk density (BD), and porosity (TPO) (Pan et al., 2017). Following the removal of

111 impurities, the $\mathrm{NO}_{3}{ }^{-}-\mathrm{N}, \mathrm{NH}_{4}{ }^{+}-\mathrm{N}, \mathrm{AP}, \mathrm{AK}, \mathrm{pH}$ value, electrical conductivity value (EC), total

112 phosphorus (TP), total potassium (TK), total carbon (TC), total nitrogen (TN), available

113 potassium (AK), Ca and $\mathrm{Mg}$ contents were determined. The soil $\mathrm{NO}_{3}{ }^{-}-\mathrm{N}, \mathrm{NH}_{4}{ }^{+}-\mathrm{N}, \mathrm{TP}, \mathrm{AP}$ and

114 AK were measured using an automatic discontinuous chemical analyzer (CleverChem Anna,

115 Germany) (Si et al., 2018; Yang et al., 2021). The pH value of the soil was determined using a

$116 \mathrm{pH}$ meter (Mettler Toledo, Shanghai, China) in a 1:2.5 (w/v) soil solution (Ma et al., 2021). The

117 EC value of the soil was determined using an electrical conductivity meter in a soil-water extract

118 at 1:5 at $25^{\circ}$ (Xie et al., 2019). The TC and TN of the soil were determined via an automatic

119 element analyzer (Vario EL Cube, Germany Elementar) (Wang et al., 2018). The contents of TK,

$120 \mathrm{Ca}$, and $\mathrm{Mg}$ in the soil were measured using an inductively coupled plasma emission

121 spectrometer (iCAP 6300 Series, America ThermoFisher) (Ma et al., 2019).

\section{Soil enzyme activity}

123 The fresh soil samples from the surface layer $(0-20 \mathrm{~cm})$ were air-dried and sifted through a 50

124 mesh. The activity of seven types of soil enzymes, including S-POD, S-PPO, S-UE, S-AKP, S-

125 BG, S-CBH, and S-NAG, were studied. S-AKP activity was determined by the p- 
126 nitrophenylphosphonate disodium method and S-POD activity was determined by potassium

127 permanganate titration. S-UE activity was determined by the sodium phenol-sodium

128 hypochlorite colorimetric method; S-CBH activity was determined by the phenyldisodium

129 phosphate colorimetric method; S-NAG activity was determined by the p-nitrophenol

130 colorimetric method; S-PPO activity was determined by the pyrogallic acid colorimetric method;

131 and S-BG activity was determined by the microporous plate fluorescence substrate method

132 (Dominguez et al.; 2017; Weintraub et al.; 2013). The international unit of enzyme consumption

133 per gram of soil $(\mathrm{U} / \mathrm{g})$ was used as the unit of measure.

\section{Statistical analysis}

135 SPSS 19.0 and Origin Pro 2021 software were used to analyze the comprehensive data. The data

136 derived from the different soil depths $(0-20 \mathrm{~cm}, 20-40 \mathrm{~cm}$, and $40-60 \mathrm{~cm})$ were statistically

137 analyzed by single-factor analysis of variance (ANOVA), whereas significant differences ( $p<$

138 0.05) in the physical and chemical properties of the soils of the various agroforestry systems

139 were evaluated using a minimum significant difference test (LSD). Correlation analysis was

140 employed to examine the relationships between the physical and chemical properties of the

141 different soil layers, as well as between the physical and chemical properties and enzyme activity

142 in the topsoil $(0-20 \mathrm{~cm})$. The PCA ranking performed in Origin Pro 2021 was used to analyze

143 the physical and chemical properties of the soil.

\section{RESULTS}

\section{Soil physical properties}

146 The basic physical properties of the soil samples extracted from different soil depths and

147 agroforestry patterns of pecan, including the EC, MC, BD, and TPO are shown in Fig. 1. In the

$1480-20 \mathrm{~cm}$ soil layer, the EC of PPL was significantly higher than that of the PPS and CK $(p<$ 
149 0.05). The soil MC of the PPS group was significantly higher than that of the CK $(p<0.05)$. The

150 soil BD of all the soil samples ranged $1.42 \mathrm{~g} / \mathrm{cm}^{3}$ to $1.55 \mathrm{~g} / \mathrm{cm}^{3}$. The soil BD of the PPS and CK

151 was significantly higher than that of the PPH and PPL $(p<0.05)$.

152 In the $20-40 \mathrm{~cm}$ soil layer, the EC of the CK group soil was the lowest (Fig.1 ). The MC of

153 the soil samples from the CK and PPS groups was significantly higher than that of the PPH and

154 PPL groups $(p<0.05)$. The BD of all the soil samples ranged from $1.39 \mathrm{~g} / \mathrm{cm}^{3}$ to $1.71 \mathrm{~g} / \mathrm{cm}^{3}$, and

155 the value of BD in descending order was PPS, CK, PPL, and PPH, where there was a significant

156 difference between any two $(p<0.05)$. The TPO under PPH group was significantly higher than

157 that of other groups $(p<0.05)$.

158 In the 40-60 cm soil layer, the EC of the PPL soil was significantly higher than that of the

$159 \mathrm{CK}, \mathrm{PPH}$, and PPS ( $p<0.05)$. The soil MC of the PPS group was significantly higher than that

160 of the CK group $(p<0.05)$. The difference in the soil MC between the PPH and PPS groups was

161 significant $(p<0.05)$. The BD of all the soil samples ranged from $1.02 \mathrm{~g} / \mathrm{cm}^{3}$ to $1.68 \mathrm{~g} / \mathrm{cm}^{3}$, and

162 the BD of the all three soil layers, in all modes, was PPS $>$ CK $>$ PPL $>$ PPH.

\section{Soil chemical properties}

164 There were some variations in the chemical properties of the different agroforestry systems in the

165 same soil layer (Table 1 and Fig. 2). Compared with the CK group, the agroforestry system

166 increased the content of some elements in the soil. There were significant differences in the $\mathrm{NO}_{3}{ }^{-}$

$167-\mathrm{N}, \mathrm{TN}, \mathrm{AK}, \mathrm{TK}$, and TC contents between the four pecan agroforestry systems. The average $\mathrm{pH}$

168 value of all soil layer samples ranged from 7.80 to 8.40 , and the $\mathrm{pH}$ decreased by $0.96 \%-2.41 \%$

169 in contrast to the monoculture. The content of Mg in the PPS group was significantly higher than

170 that in the PPH, PPL, and CK groups in all three soil layers $(p<0.05)$. 
172 significantly lower than those of the PPS and PPL groups $(p<0.05)$. The contents of AP, $\mathrm{NH}_{4}{ }^{+}-$

$173 \mathrm{~N}, \mathrm{AK}$, and TC in the CK group were lower than that of the soil following agroforestry. There

174 were significant differences in the soil $\mathrm{NO}_{3}{ }^{-}-\mathrm{N}$ between the PPL and the PPH, PPS, and CK

175 groups $(p<0.05)$. The TK content of the PPS group soil was significantly higher than that of the

176 PPH, PPL, and CK groups $(p<0.05)$.

\section{Soil enzyme activity}

178 Significant effects of different agroforestry groups on the S-UE, S-AKP, S-AKP, S-CBH, S-

179 NAG, S-POD and S-BG were observed (Table 2). Intercropping significantly increased the 180 activity of S-AKP in soil compared to CK $(p<0.05)$. The activity of S-POD and S-BG in the

181 PPL were significantly lower than those in the CK group $(p<0.05)$. The activity of S-CBH in 182 the PPH and PPS was significantly higher than in PPL and CK $(p<0.05)$. However, the activity 183 of S-NAG was opposite and was significantly higher in PPL and CK than in the PPH and PPS ( $p$ $184<0.05)$. soil

187 Fig. 3 summarizes the correlations between the main physical and chemical properties of the 188 treatments in the different soil layers $(0-20 \mathrm{~cm}, 20-40 \mathrm{~cm}$, and $40-60 \mathrm{~cm})$. The results revealed 189 that in the $0-20 \mathrm{~cm}$ soil layer, the EC was negatively correlated with the BD and Ca content $(p<$ 190 0.05), and positively correlated with the TPO $(p<0.05)$. Further, the BD was positively 191 correlated with the $\mathrm{Ca}$ and $\mathrm{Mg}$ contents $(p<0.001)$. The AP was positively correlated with the $192 \mathrm{TP}, \mathrm{AK}$, and TC $(p<0.05)$. The TP and AK were positively correlated with the available TN and 
193 TC $(p<0.05)$. There was a significantly positive correlation between the TN and TC $(p<0.001)$,

194 as well as between the $\mathrm{pH}$ and total carbon Ca content $(p<0.05)$.

195 In the $20-40 \mathrm{~cm}$ and $40-60 \mathrm{~cm}$ soil layers, there was a strong significant positive correlation 196 between the soil EC and $\mathrm{NO}_{3}^{-}-\mathrm{N}(p<0.001)$. The soil MC and $\mathrm{BD}$ were significantly negatively 197 correlated with the TPO $(p<0.001)$, and positively correlated with the TK $(p<0.05)$. The soil

198 BD was negatively correlated with the $\mathrm{NH}_{4}{ }^{+}-\mathrm{N}$ and positively correlated with the TK $(p<0.05)$,

199 whereas the TP was positively correlated with the Ca and Mg contents $(p<0.05)$. There was a 200 significantly positive correlation among the TK and TN, TC, $\mathrm{Ca}$, and $\mathrm{Mg}$ contents $(p<0.05)$, as 201 well as between the $\mathrm{AK}$ and $\mathrm{TN}(p<0.05)$. Further, there was a very significant positive 202 correlation among contents of TC and TN, $\mathrm{Ca}$ and $\mathrm{Mg}(p<0.001)$, and an extremely significant 203 positive correlation between contents the $\mathrm{Ca}$ and $\mathrm{Mg}(p<0.001)$.

204 The enzyme activity was affected by the physical and chemical properties of the soil (Table 205 3). The activities of S-NAG and S-AKP were significantly positively correlated with AK, TN 206 and TC, while the activity of S-CBH showed a significantly negative relationship with AK, TN 207 and TC $(p<0.05)$. The activities of S-UE, S-POD and S-BG exhibited a relatively weak correlation with the physical and chemical properties of the soil, and TK and $\mathrm{pH}$ had no significant correlation with all of the soil enzyme activities.

\section{Principal component analysis of soil physical and chemical properties}

211 Table 4 showed the weights of the 15 original variables along with the first four principal

212 components. According to the PCA ranking results, the eigenvalues of the first four ranking axes

213 were greater than 1, and the cumulative contribution rate reached $81.55 \%$ (Fig. 4, Table 3 ). The

214 main axis (PC1) contributed $32.93 \%$ of the total variance, the second principal component (PC2) 
215 explained $28.09 \%$ of the total variance, the third principal component (PC3) contributed $11.55 \%$

216 to the total variance, and the fourth principal component (PC4) contributed $8.98 \%$ to the total

217 variance.

\section{DISCUSSION}

219 The effect of agroforestry systems on the physicochemical properties of soil

220 Pecan agroforestry groups (PPH and PPL) were shown to reduce the BD, increase the MC, and 221 increase the TPO of the soil when compared with CK,. These results may be attributed to leaf

222 litter introduced by the vegetation and the distribution and penetration of the roots into the soil to 223 improve the physical properties and structure of soil (Chen et al., 2019; Stöcker et al., 2020). It

224 has been reported that soil BD increases with the soil depth (Stöcker et al., 2020). Our results 225 showed decreased $\mathrm{BD}$ in the deep soil of the PPH group, which is agreement with Ling et al. 226 (2020), and requires further investigation. Due to the decomposition of litter and chemical 227 degradation of minerals, the soil EC level increased following agroforestry (Samani et al., 2020). 228 In this study, the EC levels in the surface layer $(0-20 \mathrm{~cm})$ and subsurface layer $(20-40 \mathrm{~cm})$ of the 229 soil increased after the agroforestry of pecans. The EC levels decreased in the deeper soil layer $230(40-60 \mathrm{~cm})$ after agroforestry compared with the $\mathrm{CK}$, which may be related to the distribution of 231 the root systems and biochemical cycles of vegetation (Pierret et al., 2016). The vertical roots of 232 pecan plants are concentrated below $40 \mathrm{~cm}($ Xu et al., 2019) and their taproot depth is much 233 greater than that of intercropped plants (Hanson, 2019).

234 Earlier studies have documented the use of agricultural intercropping to improve soil 235 fertility (Du et al., 2019; Xia et al., 2019). We found that agroforestry increased the nutrient 236 content, improved nutrient utilization, and promoted nutrient cycling in the soil (Mortimer et al., 237 2018). These results may be attributed to other mechanisms, such as changes in community 
238 composition and biomass, organic matter inputs, and the microclimate or soil structure (Borden

239 et al., 2019; Wu et al., 2020). Most of the soil nutrients (e.g., AP, TP, $\left.\mathrm{NH}_{4}^{+}-\mathrm{N}, \mathrm{AK}, \mathrm{TN}, \mathrm{TC}\right)$

240 measured in the soil of the pecan agroforestry groups (PPH, PPS, and PPL) and pecan

241 monoculture (CK) during this study were increased in the surface soil. Additionally, PPS

242 increased the contents of $\mathrm{Ca}$ and $\mathrm{Mg}$ at the average soil depth. Therefore, pecan intercropping

243 was shown to improve the availability of soil nutrients to a certain extent.

244 Changes in the physicochemical properties of soil caused by intercropping may be due to

245 differences in the distribution of plant-soil roots and litter cover in the pecan agroforestry

246 systems (Cardinael et al., 2020; Li et al., 2016). The pH of the soil may affect the acid-base

247 balance of microbial cells and regulate the utilization of soil nutrients (Kemmitt et al., 2006). In

248 our study, the soil $\mathrm{pH}$ was lower than that of the pecan monocropping after planting crops in the

249 pecan plantation, indicating that agroforestry may improve the soil $\mathrm{pH}$, and maintain soil

250 productivity. These findings were congruent with the findings of $\mathrm{Hu}$ et al. (2019). Key biological

251 functions of plant roots such as water and nutrient uptake, respiraton, and exudation alter $\mathrm{pH}$ in

252 the soil (Rudolph et al,. 2013). Our data revealed that the soil $\mathrm{pH}$ was lower at the surface layer

$253(0-20 \mathrm{~cm})$ than the deeper soil layers. This effect may be attributed to the shallower root

254 distribution of $P$. suffruticosa and $H$. citrina, which was consistent with the results of

255 Andrianarisoa et al. (2016). The $\mathrm{pH}$ value of topsoil decreased after intercropping, which

256 prevented excessive soil alkalization.

257 Different effects of agricultural and tree intercropping on enzyme activity in the surface 258 soil of pecan plantation

259 Enzyme activity is a critical index of soil fertility and quality and is important in the soil's

260 biochemical function (Nannipieri et al., 2017). We found that some of the enzyme activity from 
261 pecan cultivation was significantly higher than that of the single cultivation of pecans. These

262 results were consistent with the findings of other intercropping systems (Clivot et al., 2019; Ma

263 et al., 2017). Thus, a better understanding of these seven enzymes can clarify the role of

264 agroforestry systems to improve soil fertility. Soil S-UE, S-BG, S-CBH, S-NAG, and S-AKP are

265 all hydrolases. Among them, S-BG and S-CBH are involved in the C cycle, S-UE and S-NAG

266 are involved in the $\mathrm{N}$ cycle, and S-AKP participates in the P cycle (Adetunji et al., 2017; Li et al.,

267 2019). In the present study, S-POD and S-PPO were oxidoreductases, and oxidoreductase was

268 involved in the synthesis of soil humus components and in the process of soil formation, which

269 helps to understand the nature of soil occurrence and related soil fertility (Ananbeh et al., 2019).

Our research found that in the surface soil, the S-UE, S-AKP, and S-NAG activity of the

soil were significantly increased under the agroforestry system when compared to CK. However,

the S-BG and S-POD activity of PPL intercropping significantly declined, when compared with

the CK, which may be attributed to the fact that soil moisture affects the biochemical process of soil carbon conversion catalyzed by S-BG (Zhang et al., 2011). The S-BG enzyme activity is

275 reduced when soil moisture decreases, which reduces the nutrient renewal speed and lowers the supply of plant nutrients (Adetunji et al., 2017). Compared with CK, the S-PPO and S-CBH activity significantly decreased in soils under PPS intercropping. This may be due to the competition and interaction between different species under different compound management modes (particularly root system and root exudates), which affected crop water and nutrient 280 absorption (Karaca et al., 2010). soil $\mathrm{C}, \mathrm{N}$, and $\mathrm{P}$ in various systems, which confirmed the key roles of these soil enzymes in carbon and nitrogen cycling in the ambient environment (Philippot et al., 2013). Contents of AK, 
284 TN and TC were highly correlated with the activity of S-AKP, S-CBH, and S-NAG, and had the

285 strongest correlation with S-NAG enzyme activity, which better explained the changes in S-

286 NAG enzyme activity. TP was highly positively correlated with S-AKP, which indicated that TP

287 was the main factor that directly or indirectly influenced the activity of S-AKP, which may have

288 been due to its positive feedback effect. Although the roles of some enzymes studied in the

289 nutrient cycle were not evident, their ability to promote the decomposition of plant litter

290 appeared to explain the increased content of these elements in the soil, which was expected

291 (Feng et al., 2019).

292 CONCLUSIONS

293 Our research investigated the changes of soil quality associated with the conversion of pecans

294 from a single crop to agroforestry. The purpose of the study was to elucidate how pecans can

295 benefit from intercropping in young plantations, particularly relating to the improvement of

296 physicochemical properties and enzyme activity. The results revealed that compared with pecan

297 monocropping, the agroforestry systems were beneficial for improving the physical properties of

298 the soil and optimizing the soil structure. Moreover, the test results showed that intercropping

299 had a certain effect on soil nutrients, improved nutrient utilization efficiency, and increased soil

300 enzyme activity to promote soil TC, TN, and TP nutrient cycling. Therefore, these systems can

301 be incorporated for sustainable soil management practices so that farmers can obtain the best use

302 of resources with limited land. Our research results have significant implications for the

303 development and management of pecan agroforestry systems. This study can facilitate the

304 maintaining of balance in the agroforestry systems; however, it is also necessary to conduct

305 further in-depth studies on the root distribution and enzyme activity of intercropping plants, to

306 correlate their changes with microbial composition, while understanding their regulatory

307 mechanisms. 
309 ACKNOWLEDGEMENTS

310 The authors would like to thank Mingyuan Gu, Lei Wang, and Lei Zhao of the Anhui

311 Agricultural University for their support in the collection of field data and soil processing.

312

313 Table 1

314 The basic chemical properties of soils in various agroforestry systems in different soil layers.

315 The lowercase letters indicate that there are diverse agroforestry systems within the same soil

316 layer showing a significant difference $(p<0.05)$.

317

318 Table 2

319 Activities of seven main enzymes in the topsoil of different pecan agroforestry systems.

320 S-UE, urease; S-AKP, alkalinephosphatase; S-PPO, polyphenoloxidase; S-CBH,

321 cellobiohydrolase; S-NAG, 1,4- $\beta$-N-acetylglucosaminidase; S-POD, peroxidase; S-BG, $\beta$-1,4-

322 glucosidase. The lowercase letters indicate that the various agroforestry systems in the same soil

323 layer were different. The difference was significant $(p<0.05)$.

324

325 Table 3

326 Pearson correlation coefficient between soil physical and chemical properties and soil enzyme 327 activities in $0-20 \mathrm{~cm}$ soil layer. 
*Significance is $p<0.05$

330

331

**Significance is $p<0.01$

332

333

$* * *$ Significance is $p<0.001$

334

335

Soil physical and chemical properties include: EC, MC, BD, TPO, AP, TP, NH4+- N, NO3--N, 336 CBH, S-NAG, S-POD, S-BG.

Table 4

Loads and explained variances of 15 original variables in the first four principal components in

341 principal component analysis (PCA).

$343 \quad$ Figure 1

344 Soil physical properties under different soil layers and different agroforestry patterns.

345 (A) changes of soil EC value; (B) changes of soil MC; (C) changes of soil BD; (D) changes of 346 soil TPO. There were significant differences in one-way ANOVA of different compound 347 patterns as indicated by different letters (LSD, $p<0.05$ ). 
349 Figure 2

350 Soil $\mathrm{pH}(\mathrm{A}), \mathrm{Ca}(\mathrm{B}), \mathrm{Mg}(\mathrm{C})$ in different soil layers under various agroforestry systems.

351 The lowercase letters indicate that diverse agroforestry systems in the same soil layer were

352 different, and the difference was significant $(p<0.05)$.

353

$354 \quad$ Figure 3

355 Correlation matrix between soil physical and chemical properties in different soil layers.

357 The correlation matrix between physical and chemical properties in the $0-20 \mathrm{~cm}$ soil (A); $20-40$

$358 \mathrm{~cm}$ correlation matrix between soil physical and chemical properties (B); 40-60 cm correlation 359 matrix between soil physical and chemical properties (C).

361 S-UE, urease; S-AKP, alkalinephosphatase; S-PPO, polyphenoloxidase; S-CBH, 362 cellobiohydrolase; S-NAG, 1,4- $\beta$-N-acetylglucosaminidase; S-POD, peroxidase; S-BG, $\beta-1,4-$ 363 glucosidase.

366 PCA ranking of soil physical and chemical properties of different pecan agroforestry models. 
367 The blue arrows indicate soil physical and chemical factors. Plots are represented by different

368 color symbols. Specifically, black squares indicate PPH; red squares represent PPS; green

369 squares represent PPL; blue squares represent CK. The abbreviations of soil physical and

370 chemical properties are shown in Figure 2. There was a significant correlation between the angle

371 of intersection and its corresponding variable, where an acute angle represents a positive

372 correlation, an obtuse angle represents a negative correlation, and a right angle represents an

373 insignificant correlation.

374

375

376

377

378

379

380

381

382

383

384

385

386

387

388

389

390

391

392

393

394

395

396

397

398

399

400

401

402

403

404

405

\section{REFERENCES}

Adetunji AT, Lewu FB, Mulidzi R, and Ncube B. 2017. The biological activities of $\beta$ glucosidase, phosphatase and urease as soil quality indicators: a review. Journal of Soil Science and Plant Nutrition 17(3):794-807 10.4067/S0718-95162017000300018

Ananbeh H, Stojanović M, Pompeiano A, Voběrková S, and Trasar-Cepeda C. 2019. Use of soil enzyme activities to assess the recovery of soil functions in abandoned coppice forest systems. Science of the Total Environment 694:133692 10.1016/j.scitotenv.2019.133692

Andrianarisoa KS, Dufour L, Bienaime S, Zeller B, and Dupraz C. 2016. The introduction of hybrid walnut trees (Juglans nigra $\mathrm{x}$ regia cv. NG23) into cropland reduces soil mineral $\mathrm{N}$ content in autumn in southern France. Agroforestry Systems 90(2):193-205 10.1007/s10457-015-9845-3

Atanasov AG, Sabharanjak SM, Zengin G, Mollica A, Szostak A, Simirgiotis M, Huminiecki L, Horbanczuk OK, Nabavi SM, and Mocan A. 2018. Pecan nuts: A review of reported bioactivities and health effects. Trends in Food Science \& Technology 71:246-257 10.1016/j.tifs.2017.10.019

Borden KA, Thomas SC, and Isaac ME. 2019. Variation in fine root traits reveals nutrientspecific acquisition strategies in agroforestry systems. Plant and Soil 453(1-2):139-151 10.1007/s11104-019-04003-2

Cardinael R, Mao Z, Chenu C, and Hinsinger P. 2020. Belowground functioning of agroforestry systems: recent advances and perspectives. Plant and Soil 453(1-2):1-13 10.1007/s11104-020-04633-X

Chen C, Liu W, Wu J, Jiang X, and Zhu X. 2019. Can intercropping with the cash crop help improve the soil physico-chemical properties of rubber plantations? Geoderma 335:149160 10.1016/j.geoderma.2018.08.023

Clivot H, Petitjean C, Marron N, Dalle E, Genestier J, Blaszczyk N, Santenoise P, Laflotte A, and Piutti S. 2019. Early effects of temperate agroforestry practices on soil organic matter and microbial enzyme activity. Plant and Soil 453(1-2):189-207 10.1007/s11104019-04320-6

Dollinger J, and Jose S. 2018. Agroforestry for soil health. Agroforestry Systems 92(2):213-219 $10.1007 / \mathrm{s} 10457-018-0223-9$

Domínguez MT, Holthof E, Smith AR, Koller E, and Emmett BA. 2017. Contrasting response of summer soil respiration and enzyme activities to long-term warming and 
406

407

408

409

410

411

412

413

414

415

416

417

418

419

420

421

422

423

424

425

426

427

428

429

430

431

432

433

434

435

436

437

438

439

440

441

442

443

444

445

446

447

448

449

450

drought in a wet shrubland (NE Wales, UK). Applied Soil Ecology 110:151-155 10.1016/j.apsoil.2016.11.003

Du B, Pang J, Hu B, Allen DE, Bell TL, Pfautsch S, Netzer F, Dannenmann M, Zhang S, and Rennenberg H. 2019. N2-fixing black locust intercropping improves ecosystem nutrition at the vulnerable semi-arid Loess Plateau region, China. Science of the Total Environment 688:333-345 10.1016/j.scitotenv.2019.06.245

Feng C, Ma YH, Jin X, Wang Z, Ma Y, Fu SL, and Chen HYH. 2019. Soil enzyme activities increase following restoration of degraded subtropical forests. Geoderma 351:180-187 10.1016/j.geoderma.2019.05.006

Fernandes GD, Gómez-Coca RB, Pérez-Camino MdC, Moreda W, and Barrera-Arellano D. 2017. Chemical characterization of major and minor compounds of nut oils: almond, hazelnut, and pecan nut. Journal of Chemistry 2017:1-11 10.1155/2017/2609549

Gao PX, Zheng XF, Wang L, Liu B, and Zhang SX. 2019. Changes in the Soil Bacterial Community in a Chronosequence of Temperate Walnut-Based Intercropping Systems. Forests 10(4):299 10.3390/f10040299

Hanson A. 2019. CRC Handbook of Plant Science in Agriculture: CRC Press.

Hu R, Zhang Z, Lin L, Liao Ma, Tang Y, Liang D, Xia H, Wang J, Wang X, Lv X, and Ren W. 2019. Intercropping with hyperaccumulator plants decreases the cadmium accumulation in grape seedlings. Acta Agriculturae Scandinavica, Section B - Soil \& Plant Science 69(4):304-310 10.1080/09064710.2018.1564786

Isbell F, Adler PR, Eisenhauer N, Fornara D, Kimmel K, Kremen C, Letourneau DK, Liebman M, Polley HW, Quijas S, and Scherer-Lorenzen M. 2017. Benefits of increasing plant diversity in sustainable agroecosystems. Journal of Ecology 105(4):871$87910.1111 / 1365-2745.12789$

Karaca A, Cetin SC, Turgay OC, and Kizilkaya R. 2010. Soil Enzymes as Indication of Soil Quality. Soil Enzymology: Springer, 119-148.

Kemmitt S, Wright D, Goulding K, and Jones D. 2006. $\mathrm{pH}$ regulation of carbon and nitrogen dynamics in two agricultural soils. Soil biology and biochemistry 38(5):898-911 10.1016/j.soilbio.2005.08.006

Kimura E, Fransen SC, Collins HP, Stanton BJ, Himes A, Smith J, Guy SO, and Johnston WJ. 2018. Effect of intercropping hybrid poplar and switchgrass on biomass yield, forage quality, and land use efficiency for bioenergy production. Biomass and Bioenergy 111:31-38 10.1016/j.biombioe.2018.01.011

Li QS, Wu LK, Chen J, Khan MA, Luo XM, and Lin WX. 2016. Biochemical and microbial properties of rhizospheres under maize/peanut intercropping. Journal of integrative agriculture 15(1):101-110 10.1016/S2095-3119(15)61089-9

Li T, Gao J, Bai L, Wang Y, Huang J, Kumar M, and Zeng X. 2019. Influence of green manure and rice straw management on soil organic carbon, enzyme activities, and rice yield in red paddy soil. Soil and Tillage Research 195:104428 10.1016/j.still.2019.104428

Lian T, Mu Y, Jin J, Ma Q, Cheng Y, Cai Z, and Nian H. 2019. Impact of intercropping on the coupling between soil microbial community structure, activity, and nutrient-use efficiencies. Peerj 7:e6412 10.7717/peerj.6412

Ling Q, Zhao X, Wu P, Gao X, and Sun W. 2020. Effect of the fodder species canola (Brassica napus L.) and daylily (Hemerocallis fulva L.) on soil physical properties and 
451

452

453

454

455

456

457

458

459

460

461

462

463

464

465

466

467

468

469

470

471

472

473

474

475

476

477

478

479

480

481

482

483

484

485

486

487

488

489

490

491

492

493

494

495

496

soil water content in a rainfed orchard on the semiarid Loess Plateau, China. Plant and Soil 453(1):209-228 10.1007/s11104-019-04318-0

Lu S, Meng P, Zhang JS, Yin CJ, and Sun SY. 2015. Changes in soil organic carbon and total nitrogen in croplands converted to walnut-based agroforestry systems and orchards in southeastern Loess Plateau of China. Environmental Monitoring and Assessment 187(11):688 10.1007/s10661-014-4131-9

Luo X, Li Z, Sun Z, and Wan X. 2016. Analysis of pecan cultivars Mahan and Western in East China. Genetics and Molecular Research 15(3): 12 10.4238/gmr.15038732

Ma H, Egamberdieva D, Wirth S, Li Q, Omari RA, Hou M, and Bellingrath-Kimura SD. 2019. Effect of Biochar and Irrigation on the Interrelationships among Soybean Growth, Root Nodulation, Plant P Uptake, and Soil Nutrients in a Sandy Field. Sustainability 11(23): 6542 10.3390/su11236542

Ma Y-h, Fu S-l, Zhang X-p, Zhao K, and Chen HYH. 2017. Intercropping improves soil nutrient availability, soil enzyme activity and tea quantity and quality. Applied Soil Ecology 119:171-178 10.1016/j.apsoil.2017.06.028

Ma Y, Feng C, Wang Z, Huang C, Huang X, Wang W, Yang S, Fu S, and Chen HYH. 2021. Restoration in degraded subtropical broadleaved forests induces changes in soil bacterial communities. Global Ecology and Conservation 30:e01775 10.1016/j.gecco.2021.e01775

Martinez-Casillas DC, Mascorro-Gutierrez I, Arreola-Ramos CE, Villafan-Vidales HI, Arancibia-Bulnes CA, Ramos-Sanchez VH, and Cuentas-Gallegos AK. 2019. A sustainable approach to produce activated carbons from pecan nutshell waste for environmentally friendly supercapacitors. Carbon 148:403-412 10.1016/j.carbon.2019.04.017

Mortimer R, Saj S, and David C. 2018. Supporting and regulating ecosystem services in cacao agroforestry systems. Agroforestry Systems 92(6):1639-1657 10.1007/s10457-017-01136

Muchane MN, Sileshi GW, Gripenberg S, Jonsson M, Pumariño L, and Barrios E. 2020. Agroforestry boosts soil health in the humid and sub-humid tropics: A meta-analysis. Agriculture, Ecosystems \& Environment 295 10.1016/j.agee.2020.106899

Nannipieri P, Trasar-Cepeda C, and Dick RP. 2017. Soil enzyme activity: a brief history and biochemistry as a basis for appropriate interpretations and meta-analysis. Biology and Fertility of Soils 54(1):11-19 10.1007/s00374-017-1245-6

Pan J, Bai Z, Cao Y, Zhou W, and Wang J. 2017. Influence of soil physical properties and vegetation coverage at different slope aspects in a reclaimed dump. Environmental Science and Pollution Research 24(30):23953-23965 10.1007/s11356-017-9974-5

Paul OO, Sekhon BS, and Sharma S. 2018. Spatial variability and simulation of soil organic carbon under different land use systems: geostatistical approach. Agroforestry Systems 93(4):1389-1398 10.1007/s10457-018-0244-4

Paz-Ferreiro J, and Fu S. 2013. Biological Indices for Soil Quality Evaluation: Perspectives and Limitations. Land Degradation \& Development 27(1):14-25 10.1002/1dr.2262

Philippot L, Raaijmakers JM, Lemanceau P, and van der Putten WH. 2013. Going back to the roots: the microbial ecology of the rhizosphere. Nature Reviews Microbiology 11(11):789-799 10.1038/nrmicro3109

Pierret A, Maeght J-L, Clément C, Montoroi J-P, Hartmann C, and Gonkhamdee S. 2016. Understanding deep roots and their functions in ecosystems: an advocacy for more unconventional research. Annals of Botany 118(4):621-635 10.1093/aob/mcw130

Peer) reviewing PDF | (2021:07:63189:2:0:NEW 9 Nov 2021) 
497

498

499

500

501

502

503

504

505

506

507

508

509

510

511

512

513

514

515

516

517

518

519

520

521

522

523

524

525

526

527

528

529

530

531

532

533

534

535

536

537

538

539

540

541

542

Ren C, Kang D, Wu Jp, Zhao F, Yang G, Han X, Feng Y, and Ren G. 2016. Temporal variation in soil enzyme activities after afforestation in the Loess Plateau, China. Geoderma 282:103-111 10.1016/j.geoderma.2016.07.018

Rillig MC, Ryo M, Lehmann A, Aguilar-Trigueros CA, Buchert S, Wulf A, Iwasaki A, Roy J, and Yang G. 2019. The role of multiple global change factors in driving soil functions and microbial biodiversity. Science 366(6467):886-890 10.1126/science.aay 2832

Rudolph N, Voss S, Moradi AB, Nagl S, and Oswald SE. 2013. Spatio-temporal mapping of local soil $\mathrm{pH}$ changes induced by roots of lupin and soft-rush. Plant and Soil 369(1):669680 10.1007/s11104-013-1775-0

Sagaram M, Lombardini L, and Grauke LJ. 2007. Variation in leaf anatomy of pecan cultivars from three ecogeographic locations. Journal of the American Society for Horticultural Science 132(5):592-596 10.21273/jashs.132.5.592

Sagastuy M, and Krause T. 2019. Agroforestry as a Biodiversity Conservation Tool in the Atlantic Forest? Motivations and Limitations for Small-Scale Farmers to Implement Agroforestry Systems in North-Eastern Brazil. Sustainability 11(24):6932 $10.3390 /$ su11246932

Samani KM, Pordel N, Hosseini V, and Shakeri Z. 2020. Effect of land-use changes on chemical and physical properties of soil in western Iran (Zagros oak forests). Journal of Forestry Research 31(2):637-647 10.1007/s11676-018-0799-y

Santos PZF, Crouzeilles R, and Sansevero JBB. 2019. Can agroforestry systems enhance biodiversity and ecosystem service provision in agricultural landscapes? A meta-analysis for the Brazilian Atlantic Forest. Forest Ecology and Management 433:140-145 10.1016/j.foreco.2018.10.064

Si P, Shao W, Yu H, Yang X, Gao D, Qiao X, Wang Z, and Wu G. 2018. Rhizosphere Microenvironments of Eight Common Deciduous Fruit Trees Were Shaped by Microbes in Northern China. Frontiers in Microbiology 9(3147) 10.3389/fmicb.2018.03147

Stöcker CM, Bamberg AL, Stumpf L, Monteiro AB, Cardoso JH, and de Lima ACR. 2020. Short-term soil physical quality improvements promoted by an agroforestry system. Agroforestry Systems 94(5):2053-2064 10.1007/s10457-020-00524-3

Tafesa S, Chimdi A, and Aga E. 2019. Impacts of deforestation on selected soil fertility status: the case of Cheliya District, West Shoa Zone, Oromia national regional state, Ethiopia. Journal of Science and Sustainable Development 7(2):29-40 10.20372/au.jssd.7.2.2019.0135

Tang X, Zhong R, Jiang J, He L, Huang Z, Shi G, Wu H, Liu J, Xiong F, Han Z, Tang R, and He L. 2020. Cassava/peanut intercropping improves soil quality via rhizospheric microbes increased available nitrogen contents. Bmc Biotechnology 20(1):13 10.1186/s12896-020-00606-1

Torralba M, Fagerholm N, Burgess PJ, Moreno G, and Plieninger T. 2016. Do European agroforestry systems enhance biodiversity and ecosystem services? A meta-analysis. Agriculture Ecosystems \& Environment 230:150-161 10.1016/j.agee.2016.06.002

Wang C, Lu X, Mori T, Mao Q, Zhou K, Zhou G, Nie Y, and Mo J. 2018. Responses of soil microbial community to continuous experimental nitrogen additions for 13 years in a nitrogen-rich tropical forest. Soil biology and biochemistry 121:103-112 10.1016/j.soilbio.2018.03.009

Wang J, Ren C, Cheng H, Zou Y, Bughio MA, and Li Q. 2017. Conversion of rainforest into agroforestry and monoculture plantation in China: Consequences for soil phosphorus

Peer) reviewing PDF | (2021:07:63189:2:0:NEW 9 Nov 2021) 
543

544

545

546

547

548

549

550

551

552

553

554

555

556

557

558

559

560

561

562

563

564

565

566

567

568

569

570

571

572

573

574

575

576

577

578

579

580

581

582

583 forms and microbial community. Science of the Total Environment 595:769-778 10.1016/j.scitotenv.2017.04.012

Weintraub SR, Wieder WR, Cleveland CC, and Townsend AR. 2013. Organic matter inputs shift soil enzyme activity and allocation patterns in a wet tropical forest. Biogeochemistry 114(1):313-326 10.1007/s10533-012-9812-2

Wilson MH, and Lovell ST. 2016. Agroforestry-The next step in sustainable and resilient agriculture. Sustainability 8(6):574 10.3390/su8060574

Wu J, Zeng H, Zhao F, Chen C, Liu W, Yang B, and Zhang W. 2020. Recognizing the role of plant species composition in the modification of soil nutrients and water in rubber agroforestry systems. Science of the Total Environment 723:138042 10.1016/j.scitotenv.2020.138042

Xia JB, Ren JY, Zhang SY, Wang YH, and Fang Y. 2019. Forest and grass composite patterns improve the soil quality in the coastal saline-alkali land of the Yellow River Delta, China. Geoderma 349:25-35 10.1016/j.geoderma.2019.04.032

Xie X, Pu L, Zhu M, Xu Y, and Wang X. 2019. Linkage between soil salinization indicators and physicochemical properties in a long-term intensive agricultural coastal reclamation area, Eastern China. Journal of Soils and Sediments 19(11):3699-3707 10.1007/s11368019-02333-3

Xu R, Wang Z, Luo Y, Zhang N, Liang C, and Zhu G. 2019. Effect of intercropping peonies under walnut trees for growth and development of roots in two kinds of soil. IOP Conference Series: Earth and Environmental Science: IOP Publishing. p 012024.

Yang S, Feng C, Ma Y, Wang W, Huang C, Qi C, Fu S, and Chen HYH. 2021. Transition from $\mathrm{N}$ to $\mathrm{P}$ limited soil nutrients over time since restoration in degraded subtropical broadleaved mixed forests. Forest Ecology and Management 494:119298 10.1016/j.foreco.2021.119298

Yang Y-z, Zhang Z-h, and Li J. 2018. Photosynthetic characteristics of oil peony Paeonia ostii under different intercropping patterns and their relationships with environmental factors. Chinese Journal of Ecology 37(10):2905 10.13292/j.1000-4890.201810.023

Žalac H, Burgess P, Graves A, Giannitsopoulos M, Paponja I, Popović B, and Ivezić V. 2021. Modelling the yield and profitability of intercropped walnut systems in Croatia. Agroforestry Systems 10.1007/s10457-021-00611-z

Zhang R, Peng FR, and Li YR. 2015. Pecan production in China. Scientia Horticulturae 197:719-727 10.1016/j.scienta.2015.10.035

Zhang X, Teng Z, Zhang H, Cai D, Zhang J, Meng F, and Sun G. 2021. Nitrogen application and intercropping change microbial community diversity and physicochemical characteristics in mulberry and alfalfa rhizosphere soil. Journal of Forestry Research 10.1007/s11676-020-01271-y

Zhang Y, Chen L, Wu Z, and Sun C. 2011. Kinetic parameters of soil $\beta$-glucosidase response to environmental temperature and moisture regimes. Revista Brasileira De Ciencia Do Solo 35(4):1285-1291 10.1590/s0100-06832011000400022 


\section{Table 1 (on next page)}

Basic chemical properties of soils in various agroforestry systems in different soil layers

The lowercase letters of different agroforestry systems in the same soil layer were different, and the difference was significant $(P<0.05)$. 


\begin{tabular}{|c|c|c|c|c|c|c|c|c|}
\hline Treatments & $\begin{array}{c}\mathrm{AP} \\
(\mathrm{mg} / \mathrm{kg})\end{array}$ & $\begin{array}{c}\mathrm{TP} \\
(\mathrm{g} / \mathrm{kg})\end{array}$ & $\begin{array}{l}\mathrm{NH}_{4}{ }^{+}-\mathrm{N} \\
(\mathrm{mg} / \mathrm{kg})\end{array}$ & $\begin{array}{l}\mathrm{NO}_{3}{ }^{-}-\mathrm{N} \\
(\mathrm{mg} / \mathrm{kg})\end{array}$ & $\begin{array}{c}\mathrm{TN} \\
(\mathrm{g} / \mathrm{kg})\end{array}$ & $\begin{array}{c}\mathrm{AK} \\
(\mathrm{mg} / \mathrm{kg})\end{array}$ & $\begin{array}{c}\text { TK } \\
(\mathrm{g} / \mathrm{kg})\end{array}$ & $\begin{array}{c}\mathrm{TC} \\
(\mathrm{g} / \mathrm{kg})\end{array}$ \\
\hline $0-20 \mathrm{~cm}$ & $\square$ & $\square$ & $\square$ & $\square$ & $\square$ & $\square$ & $\square$ & $\square$ \\
\hline PPH & $9.99 \pm 2.13 \mathrm{a}$ & $1.72 \pm 0.14 \mathrm{ab}$ & $0.69 \pm 0.36 \mathrm{a}$ & $2.34 \pm 1.21 \mathrm{~b}$ & $0.94 \pm 0.12 \mathrm{a}$ & $244.27 \pm 55.22 \mathrm{a}$ & $3.18 \pm 0.42 b$ & $16.40 \pm 1.62 \mathrm{a}$ \\
\hline PPS & $10.42 \pm 1.47 \mathrm{a}$ & $1.98 \pm 0.37 \mathrm{a}$ & $0.61 \pm 0.52 \mathrm{a}$ & $1.76 \pm 0.78 b$ & $0.94 \pm 0.04 \mathrm{a}$ & $223.70 \pm 61.20 \mathrm{a}$ & $4.15 \pm 0.33 \mathrm{ab}$ & $16.54 \pm 0.42 \mathrm{a}$ \\
\hline PPL & $8.43 \pm 1.81 \mathrm{a}$ & $1.84 \pm 0.23 \mathrm{a}$ & $0.38 \pm 0.14 \mathrm{a}$ & $6.08 \pm 2.28 \mathrm{a}$ & $0.87 \pm 0.03 \mathrm{a}$ & $78.37 \pm 25.26 b$ & $4.47 \pm 0.79 \mathrm{a}$ & $14.70 \pm 0.10 \mathrm{ab}$ \\
\hline $\mathrm{CK}$ & $6.76 \pm 3.21 \mathrm{a}$ & $1.29 \pm 0.26 b$ & $0.14 \pm 0.11 \mathrm{a}$ & $2.52 \pm 0.84 b$ & $0.48 \pm 0.25 b$ & $52.93 \pm 7.90 \mathrm{~b}$ & $4.34 \pm 0.80 \mathrm{ab}$ & $13.63 \pm 1.00 \mathrm{~b}$ \\
\hline $20-40 \mathrm{~cm} \square$ & $\square$ & $\square$ & $\square$ & $\square$ & $\square$ & $\square$ & $\square$ & $\square$ \\
\hline PPH & $3.58 \pm 1.73 \mathrm{a}$ & $0.98 \pm 0.02 \mathrm{a}$ & $0.89 \pm 0.35 \mathrm{a}$ & $2.82 \pm 1.92 b$ & $0.35 \pm 0.03 b$ & $149.20 \pm 42.52 \mathrm{a}$ & $2.51 \pm 0.31 \mathrm{c}$ & $12.09 \pm 0.16 b$ \\
\hline PPS & $2.19 \pm 0.90 \mathrm{a}$ & $1.15 \pm 0.04 \mathrm{a}$ & $0.32 \pm 0.04 \mathrm{~b}$ & $0.57 \pm 0.08 b$ & $0.60 \pm 0.05 \mathrm{a}$ & $147.90 \pm 11.89 \mathrm{a}$ & $4.89 \pm 0.35 \mathrm{a}$ & $16.44 \pm 0.73 a$ \\
\hline PPL & $3.05 \pm 2.73 \mathrm{a}$ & $1.12 \pm 0.16 \mathrm{a}$ & $0.47 \pm 0.15 b$ & $7.85 \pm 3.12 \mathrm{a}$ & $0.42 \pm 0.11 \mathrm{~b}$ & $119.67 \pm 27.14 \mathrm{a}$ & $4.04 \pm 0.67 \mathrm{~b}$ & $13.17 \pm 0.61 b$ \\
\hline $\mathrm{CK}$ & $1.51 \pm 0.25 \mathrm{a}$ & $1.01 \pm 0.08 \mathrm{a}$ & $0.21 \pm 0.12 b$ & $2.57 \pm 1.31 \mathrm{~b}$ & $0.29 \pm 0.06 b$ & $28.43 \pm 3.76 b$ & $3.73 \pm 0.23 b$ & $12.79 \pm 0.80 \mathrm{~b}$ \\
\hline $40-60 \mathrm{~cm}$ & $\square$ & $\square$ & $\square$ & $\square$ & $\square$ & $\square$ & $\square$ & $\square$ \\
\hline PPH & $2.25 \pm 1.07 \mathrm{a}$ & $0.96 \pm 0.07 \mathrm{a}$ & $0.60 \pm 0.10 \mathrm{a}$ & $2.14 \pm 0.96 b$ & $0.21 \pm 0.04 b$ & $97.60 \pm 40.45 \mathrm{ab}$ & $2.17 \pm 0.48 b$ & $11.39 \pm 0.19 b$ \\
\hline PPS & $1.25 \pm 0.46 \mathrm{a}$ & $1.10 \pm 0.06 \mathrm{a}$ & $0.29 \pm 0.20 \mathrm{~b}$ & $0.56 \pm 0.25 b$ & $0.37 \pm 0.06 \mathrm{a}$ & $113.27 \pm 23.08 \mathrm{a}$ & $4.76 \pm 1.25 \mathrm{a}$ & $19.68 \pm 0.62 \mathrm{a}$ \\
\hline PPL & $1.32 \pm 0.08 \mathrm{a}$ & $1.07 \pm 0.22 \mathrm{a}$ & $0.28 \pm 0.10 \mathrm{~b}$ & $9.76 \pm 2.33 \mathrm{a}$ & $0.25 \pm 0.11 \mathrm{ab}$ & $58.10 \pm 25.75 b c$ & $3.52 \pm 0.95 \mathrm{ab}$ & $12.52 \pm 1.98 \mathrm{~b}$ \\
\hline $\mathrm{CK}$ & $2.58 \pm 2.85 \mathrm{a}$ & $0.92 \pm 0.05 \mathrm{a}$ & $0.16 \pm 0.14 \mathrm{~b}$ & $2.28 \pm 1.00 \mathrm{~b}$ & $0.18 \pm 0.06 \mathrm{~b}$ & $16.50 \pm 5.93 \mathrm{c}$ & $3.36 \pm 0.26 \mathrm{ab}$ & $10.85 \pm 0.18 \mathrm{~b}$ \\
\hline
\end{tabular}




\section{Table 2 (on next page)}

Activities of seven main enzymes in the topsoil of different pecan agroforestry systems

S-UE, urease; S-AKP, alkalinephosphatase; S-PPO, polyphenoloxidase; S-CBH, cellobiohydrolase; S-NAG, 1,4- $\beta$-N-acetylglucosaminidase; S-POD, peroxidase; S-BG, $\beta-1,4$ glucosidase. The lowercase letters of different agroforestry systems in the same soil layer were different, and the difference was significant $(P<0.05)$. 
1

\begin{tabular}{lccccccc}
\hline \multirow{2}{*}{ Treatment } & $\begin{array}{c}\text { S-UE } \\
(\mathrm{U} / \mathrm{g})\end{array}$ & $\begin{array}{c}\text { S-AKP } \\
(\mathrm{U} / \mathrm{g})\end{array}$ & $\begin{array}{c}\text { S-PPO } \\
(\mathrm{U} / \mathrm{g})\end{array}$ & $\begin{array}{c}\text { S-CBH } \\
(\mathrm{U} / \mathrm{g})\end{array}$ & $\begin{array}{c}\text { S-NAG } \\
(\mathrm{U} / \mathrm{g})\end{array}$ & $\begin{array}{c}\text { S-POD } \\
(\mathrm{U} / \mathrm{g})\end{array}$ & $\begin{array}{c}\text { S-BG } \\
(\mathrm{U} / \mathrm{g})\end{array}$ \\
\hline PPH & $893.89 \pm 15.12 \mathrm{bc}$ & $10.77 \pm 0.57 \mathrm{a}$ & $12.22 \pm 0.62 \mathrm{a}$ & $4.46 \pm 0.46 \mathrm{~b}$ & $6.59 \pm 1.38 \mathrm{a}$ & $4.60 \pm 0.99 \mathrm{ab}$ & $129.58 \pm 29.45 \mathrm{a}$ \\
PPS & $1018.64 \pm 67.09 \mathrm{a}$ & $11.72 \pm 0.53 \mathrm{a}$ & $9.76 \pm 0.43 \mathrm{~b}$ & $5.43 \pm 0.91 \mathrm{~b}$ & $7.14 \pm 0.38 \mathrm{a}$ & $4.91 \pm 0.76 \mathrm{ab}$ & $131.77 \pm 19.53 \mathrm{a}$ \\
PPL & $974.79 \pm 54.41 \mathrm{ab}$ & $10.86 \pm 0.98 \mathrm{a}$ & $10.85 \pm 0.63 \mathrm{ab}$ & $11.18 \pm 2.83 \mathrm{a}$ & $3.13 \pm 0.79 \mathrm{~b}$ & $3.38 \pm 1.16 \mathrm{~b}$ & $24.84 \pm 6.50 \mathrm{~b}$ \\
$\mathrm{CK}$ & $831.98 \pm 33.33 \mathrm{c}$ & $8.48 \pm 0.49 \mathrm{~b}$ & $11.50 \pm 1.39 \mathrm{a}$ & $12.52 \pm 2.12 \mathrm{a}$ & $2.39 \pm 0.58 \mathrm{~b}$ & $5.35 \pm 0.50 \mathrm{a}$ & $150.84 \pm 16.58 \mathrm{a}$ \\
\hline
\end{tabular}

2
3 


\section{Table 3 (on next page)}

Pearson correlation coefficient between soil physical and chemical properties and soil enzyme activities in 0-20 cm soil layer

*Significance is at $p<0.05$

**Significance is at $p<0.01$

$* * *$ Significance is at $p<0.001$

Soil physical and chemical properties include EC, MC, BD, TPO, AP, TP, $\mathrm{NH}_{4}{ }^{+}-\mathrm{N}, \mathbf{N O}_{\mathbf{3}}{ }^{-}-\mathbf{N}, \mathrm{TK}, \mathrm{AK}, \mathrm{TN}, \mathrm{TC}$, soil $\mathrm{pH}, \mathrm{Ca}$ and $\mathrm{Mg}$. Soil enzyme activities include S-UE, S-AKP, S-PPO, S-CBH, S-NAG, S-POD, S-BG. 


\begin{tabular}{rrrrrrrr}
\hline & S-UE & S-AKP & S-PPO & S-CBH & S-NAG & S-POD & S-BG \\
\hline EC & 0.322 & 0.411 & 0.182 & -0.150 & 0.047 & $-0.681 *$ & $-0.648^{*}$ \\
$\mathrm{MC}$ & 0.530 & $0.634^{*}$ & -0.265 & -0.284 & 0.503 & 0.180 & -0.292 \\
$\mathrm{BD}$ & 0.180 & 0.031 & $-0.653^{*}$ & -0.043 & 0.156 & 0.357 & 0.484 \\
$\mathrm{TPO}$ & -0.180 & -0.032 & $0.654^{*}$ & 0.043 & -0.156 & -0.356 & -0.483 \\
$\mathrm{AP}$ & 0.415 & 0.466 & -0.345 & -0.305 & $0.732 * *$ & 0.158 & -0.084 \\
$\mathrm{TP}$ & 0.432 & $0.691 *$ & $-0.643 *$ & -0.357 & 0.512 & -0.050 & -0.358 \\
$\mathrm{NH}_{4}{ }^{+}-\mathrm{N}$ & 0.495 & 0.425 & 0.207 & $-0.678^{*}$ & 0.572 & -0.410 & 0.032 \\
$\mathrm{NO}_{3}-\mathrm{N}$ & 0.062 & 0.009 & -0.031 & 0.461 & -0.423 & -0.383 & $-0.709 *$ \\
$\mathrm{TK}$ & 0.241 & -0.164 & -0.487 & 0.457 & -0.441 & -0.312 & -0.234 \\
$\mathrm{AK}$ & 0.194 & $0.621 *$ & -0.147 & $-0.814 * *$ & $0.874 * * *$ & 0.315 & 0.245 \\
$\mathrm{TN}$ & 0.471 & $0.749 * *$ & -0.451 & $-0.596 *$ & $0.617 *$ & -0.259 & -0.269 \\
$\mathrm{TC}$ & 0.364 & $0.677 *$ & -0.375 & $-0.730 * *$ & $0.799 * *$ & 0.132 & 0.053 \\
$\mathrm{pH}$ & 0.091 & -0.050 & -0.310 & 0.354 & -0.390 & 0.236 & -0.208 \\
$\mathrm{Ca}$ & -0.100 & -0.327 & -0.207 & 0.082 & -0.034 & $0.699 *$ & 0.447 \\
$\mathrm{Mg}$ & 0.560 & 0.427 & $-0.751 * *$ & -0.319 & 0.396 & 0.146 & 0.046 \\
\hline
\end{tabular}

2 


\section{Table 4 (on next page)}

Loads and explained variances of 15 original variables in the first 4 principal components in principal component analysis (PCA) 
1

\begin{tabular}{ccccc}
\hline \multirow{2}{*}{ Soil Physico-Chemical Properties } & \multicolumn{4}{c}{ Principal Components } \\
\cline { 2 - 5 } Soil electrical conductivity(EC) & -0.1388 & 0.0051 & 0.5871 & 0.3834 \\
Soil water content (MC) & 0.3282 & -0.1627 & 0.0525 & -0.0141 \\
Soil bulk density(BD) & 0.3717 & -0.0857 & 0.1724 & -0.1318 \\
Total porosity of soil(TPO) & -0.3717 & 0.0857 & -0.1725 & 0.1318 \\
Soil available phosphorus (AP) & 0.0319 & 0.4278 & -0.0152 & -0.248 \\
Soil total phosphorus (TP) & 0.1311 & 0.4082 & 0.1195 & -0.156 \\
Soil ammonium nitrogen(NH $\left.{ }^{+}-\mathrm{N}\right)$ & -0.1455 & 0.2207 & -0.2497 & 0.4469 \\
Soil nitrate nitrogen(NO $\left.{ }^{-}-\mathrm{N}\right)$ & -0.194 & 0.0032 & 0.6078 & 0.1857 \\
Soil total potassium (TK) & 0.3541 & -0.0017 & 0.2662 & -0.1226 \\
Soil available potassium (AK) & 0.1063 & 0.3629 & -0.1684 & 0.3398 \\
Soil total nitrogen (TN) & 0.1761 & 0.4272 & 0.0678 & -0.093 \\
Total soil carbon(TC) & 0.3804 & 0.1608 & -0.041 & 0.2386 \\
Soil pH (pH) & 0.0116 & -0.3615 & -0.1302 & -0.1667 \\
Ca & 0.2464 & -0.2976 & -0.1155 & 0.4309 \\
Mg & 0.3827 & -0.0353 & -0.1053 & 0.2977 \\
Eercentage of Variance $(\%)$ & 4.9399 & 4.2136 & 1.733 & 1.3464 \\
Cumulative (\%) & 32.93 & 28.09 & 11.55 & 8.98 \\
\hline
\end{tabular}




\section{Figure 1}

Soil physical properties under different soil layers and different agroforestry patterns

(A) changes of soil EC value (B) changes of soil MC; (C) changes of soil BD; (D) changes of soil TPO. There were significant differences in one-way ANOVA of different compound patterns with different letters (LSD, $\mathrm{P}<0.05)$.
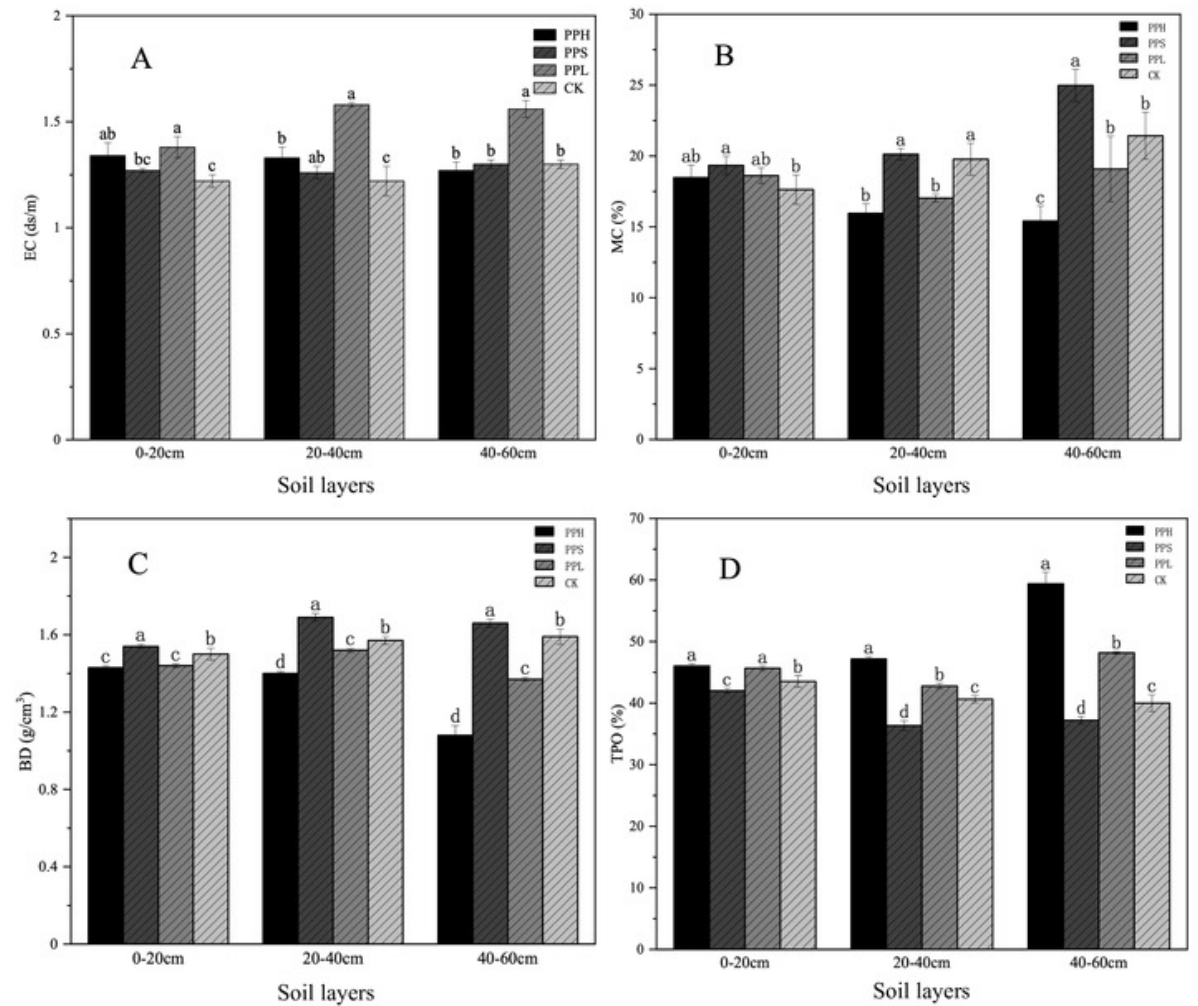


\section{Figure 2}

Soil $\mathrm{pH}(\mathrm{A}), \mathrm{Ca}(\mathrm{B}), \mathrm{Mg}(\mathrm{C})$ in different soil layers under various agroforestry systems

The lowercase letters of different agroforestry systems in the same soil layer were different, and the difference was significant $(P<0.05)$.
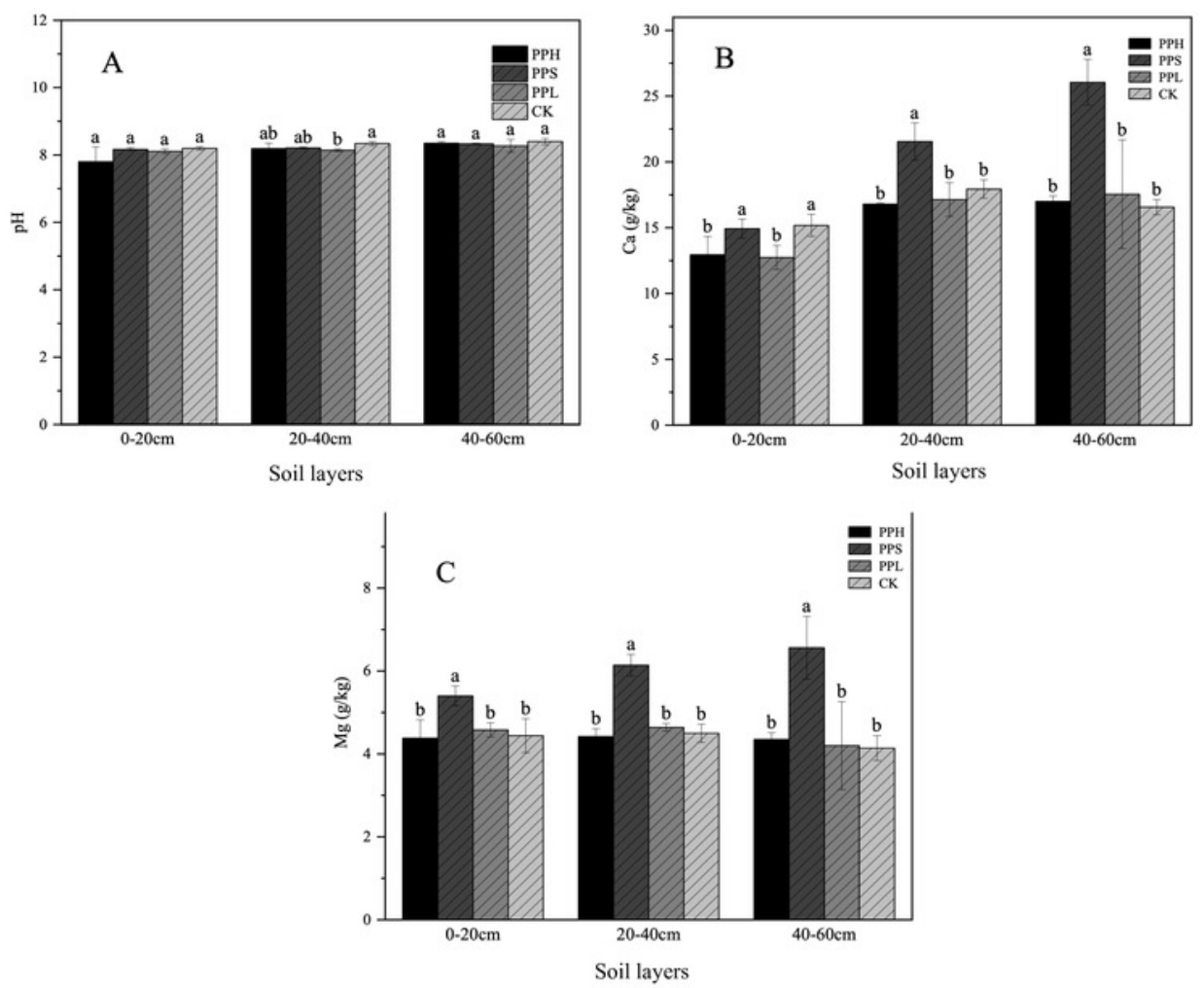
Figure 3

Correlation matrix between soil physical and chemical properties in different soil layers

Correlation matrix between physical and chemical properties of $0-20 \mathrm{~cm}$ soil (A); $20-40 \mathrm{~cm}$ correlation matrix between soil physical and chemical properties (B); $40-60 \mathrm{~cm}$ correlation matrix between soil physical and chemical properties (C).

S-UE, urease; S-AKP, alkalinephosphatase; S-PPO, polyphenoloxidase; S-CBH, cellobiohydrolase; S-NAG, 1,4$\beta$-N-acetylglucosaminidase; S-POD, peroxidase; S-BG, $\beta$-1,4-glucosidase.
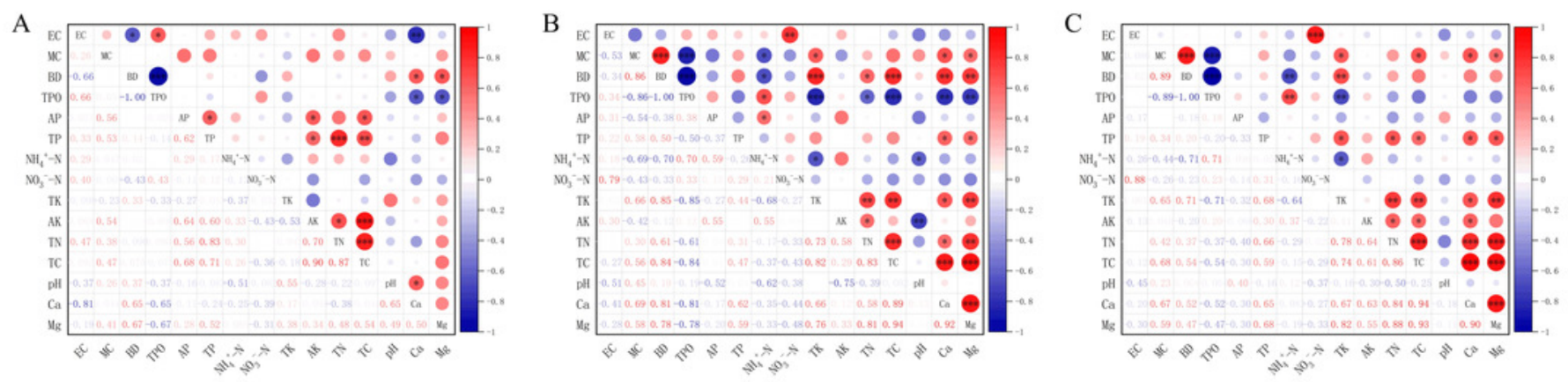


\section{Figure 4}

PCA ranking chart of soil physical and chemical properties of different pecan agroforestry models

Blue arrows indicate soil physical and chemical factors. Plots are represented by different color symbols. Specifically, black squares indicate PPH; red squares represent PPS; green squares represent PPL; blue squares represent CK. The abbreviations of soil physical and chemical properties are shown in Figure 2. There was a significant correlation between the angle of intersection and its corresponding variable, where an acute angle represents a positive correlation, an obtuse angle represents a negative correlation, and a right angle represents an insignificant correlation.

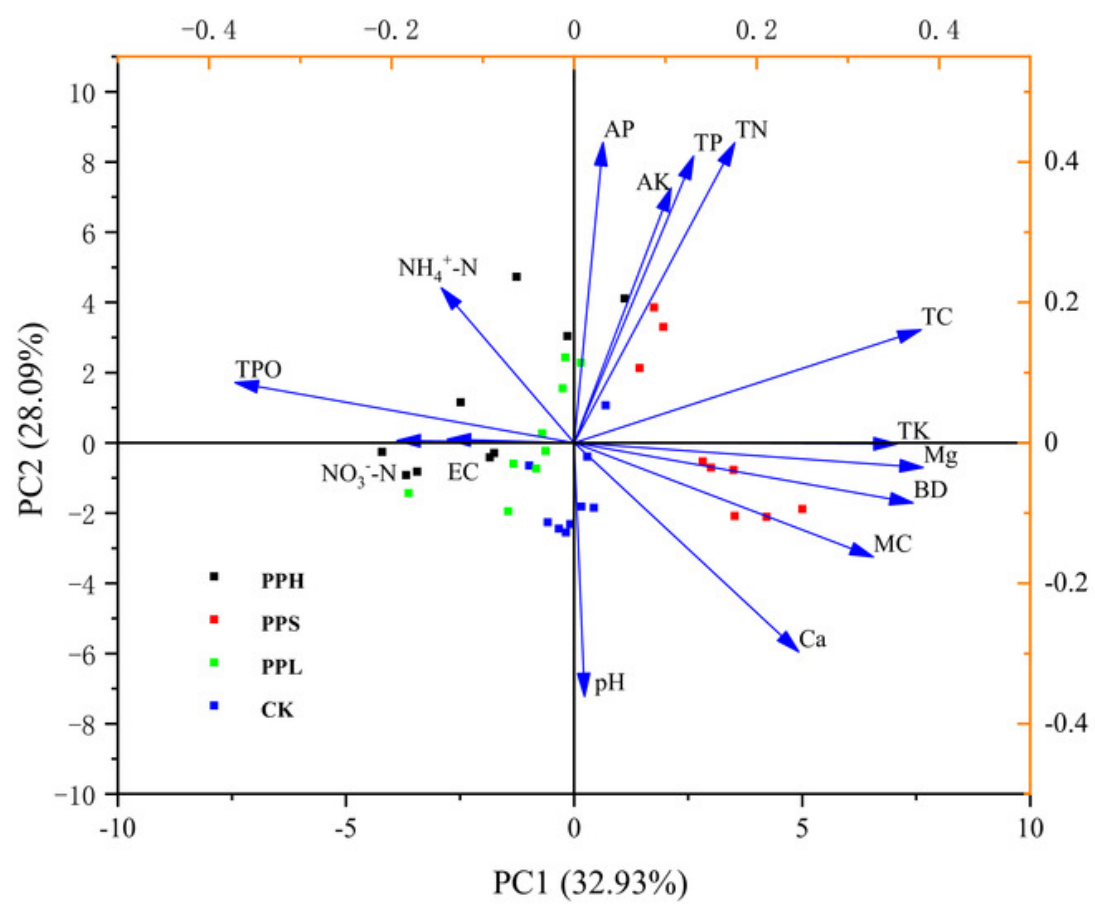

